\title{
Endoscopic Transaqueductal Removal of Fourth Ventricular Neurocysticercosis: Report of Three Cases
}

\author{
Dördüncü Ventrikül Nörosistiserkozisinin Endoskopik Transakuaduktal \\ Yolla Çıkarılması: Üç Olgu Sunumu
}

Guoqiang $\mathrm{CHEN}^{1}$, Qing $\mathrm{XIAO}^{2}$, Jiaping $\mathrm{ZHENG}^{2}$, Jinting $\mathrm{WU}^{2}$, Qiang $\mathrm{AO}^{3}$, Yunsheng $\mathrm{LIU}^{1}$

${ }_{1}^{1}$ Xiangya Hospital, Central-South University, Department of Neurosurgery, Hunan, China

${ }^{2} Y u q u a n$ Hospital, Tsinghua University, Department of Neurosurgery, Beijing, China

${ }^{3}$ China Medical University, Department of Tissue Engineering, Liaoning, China

Corresponding Author: Yunsheng LIU \& Qiang AO / E-mail: yunshen_liu@163.com

\begin{abstract}
In this study, we try to present our experience of transaqueductal removal of the fourth ventricular neurocysticercosis (FVNCC) with a flexible neuroendoscope. Three cases of the fourth ventricular cysticercosis were transaqueductally removed with FUJINON EB-270P flexible neuroendoscope through a frontal precoronal burr hole. The diagnosis was established on imaging and confirmed on histology in all of the cases. Complete excision of cysts in the fourth ventricle was performed in all cases with no significant intraoperative or postoperative complications. The shunt and the string-of-beads multiple cysts in the basal cistern were removed simultaneously through the orificium fistulae of the third ventricle floor with the flexible neuroendoscope. Satisfactory postoperative CSF flow around foramen magnum was detected by cine phase-contrast magnetic resonance imaging. All of the patients were asymptomatic, with an average follow-up of 6 months. The whole ventricular system can be explored easily with electrical flexible neuroendoscope. Endoscopic transaqueductal removal of the fourth ventricular cysticercosis with a flexible neuroendoscope should be recommended as the optimal choice of the disease due to its minimal invasion, fewer complications, shorter length of stay and cheaper treatment costs.
\end{abstract}

KEYWORDS: Fourth ventricular, Neurocysticercosis, Endoscopic transaqueductal removal, Treatment

öz

Çalışmada esnek bir nöroendoskopla dördüncü ventrikül nörosistiserkozisinin transakuaduktal eksizyonuyla ilgili deneyimimizi sunuyoruz. Üç adet dördüncü ventrikül sistiserkozis olgusu, bir frontal prekoronal burr deliği içinden FUJINON EB-270P esnek nöroendoskopuyla transakuaduktal olarak çıkarıldı. Tüm olgularda tanı görüntülemeyle kondu ve histolojiyle doğrulandı. Dördüncü ventriküldeki kistlerin tam eksizyonu tüm olgularda herhangi bir önemli intraoperatif veya postoperatif komplikasyon olmadan gerçekleştirildi. Bazal sisterndeki boncuk dizisi tarzındaki çoklu kistler ve şant, esnek nöroendoskopla üçüncü ventrikül tabanındaki fistül orifisi yoluyla aynı anda çıkarıldı. Sine faz-kontrast manyetik rezonans görüntüleme yoluyla foramen magnum etrafında tatminkar postoperatif BOS akışı gözlendi. Ortalama takip 6 aydı ve hastaların hiçbirinde belirti yoktu. Elektrikli esnek nöroendoskopla tüm ventriküler sistemin eksplorasyonu kolayca yapılabilir. Esnek bir nöroendoskopla dördüncü ventrikül sistiserkozisinin endoskopik transakuaduktal yoldan çıkarılması minimum invazyon, daha az komplikasyon, hastanede daha az kalma ve daha ucuz tedavi maliyeti nedeniyle bu hastalık için optimum tercih olarak düşünülmelidir.

ANAHTAR SÖZCÜKLER: Dördüncü ventrikül, Nörosistiserkozis, Endoskopik transakuaduktal yolla çıkarma, Tedavi

\section{INTRODUCTION}

Fourth ventricular neurocysticercosis (FVNCC) usually presents with obstructive hydrocephalus. Available treatment options are medical, external cerebrospinal fluid diversion, microsurgical, or endoscopic removal alone or in combination.

We present our experience of transaqueductal removal of FVNCC with the flexible endoscope alone.

\section{CASE REPORT}

\section{Case 1}

A 22-year-old male was diagnosed with fourth ventricular cysticercosis at the local hospital due to a cystic lesion in the fourth ventricle on MRI (Figure 1A) combined with a positive reaction on the cysticercosis immunological test on May 21, 2009. He had been suffering from an intermittent headache with projectile vomiting for 2 years, aggravated for 2 months. A standard suboccipital craniectomy for removal of cysticercal cysts within the fourth ventricle had been planned at the local hospital. In order to receive minimally invasive treatment, he was transferred to our hospital on June 5, 2009. Following the preoperative examination, a transventricular, transaqueductal removal of an intra-fourth ventricular cyst via a precoronal frontal burr hole was performed with an electrical flexible neuroendoscope on June 9, 2009 (Figure 1C-D). The headache disappeared with no adverse reaction postoperatively. The cystic lesion in the fourth ventricle disappeared (Figure 1B) and satisfactory CSF flow around 
foramen magnum was detected by cine phase-contrast magnetic resonance imaging 6 days after the operation. The diagnosis was confirmed on histology and the patient was discharged from hospital 7 days after the operation.

\section{Case 2}

A 33-year-old male was diagnosed as neurocysticercosis in local hospital according to the cranial CT scan in 2006. He was suffering from an intermittent headache and a generalised tonic seizure with no obvious precipitating factor and anthelmintic medication was taken irregularly. On May 28, 2009, the consciousness of the patient was rescued from coma secondary to sudden severe headache and vomiting by mannitol, glycerol and fructose injection in the local hospital. On June 7, 2009, coma secondary to sudden severe headache and vomiting emerged again and the consciousness was rescued by external ventricular drainage, and V-P shunt for the CSF was proposed in the local hospital. In order to avoid the shunt operation, he was transferred to our hospital on June 11, 2009. The preoperative MRI showed a cystic lesion in the third ventricle (Figure 2A) but during the course of exploration of the ventricles via a precoronal frontal burr hole which remained from external ventricular drainage under the neuroendoscope, the lesion was seen to have migrated into the fourth ventricle (Figure 2B). Transaqueductal removal of the intra-fourth ventricular cyst was performed successfully with the electrical flexible neuroendoscope. Consciousness with no headache or adverse reaction was present postoperatively. The cystic lesion in the third ventricle disappeared (Figure 2C) and satisfactory CSF flow around the foramen magnum was detected by cine phase-contrast magnetic resonance imaging 6 days after the operation. Diagnosis was confirmed on histology and the patient was discharged from hospital 7 days after operation.

\section{Case 3}

A48-year-old male was diagnosed as having neurocysticercosis for 14 years and treated with insect repellents several times. V-P shunt was performed on March 24, 2009 due to hydrocephalus diagnosed by CT scan after emergence of headache, nausea and vomiting in the local hospital. On October 20, 2009, he was admitted to our hospital because of recurrent attacks of headache and vomiting combined with fever after V-P shunt. Preoperative CT showed a cystic
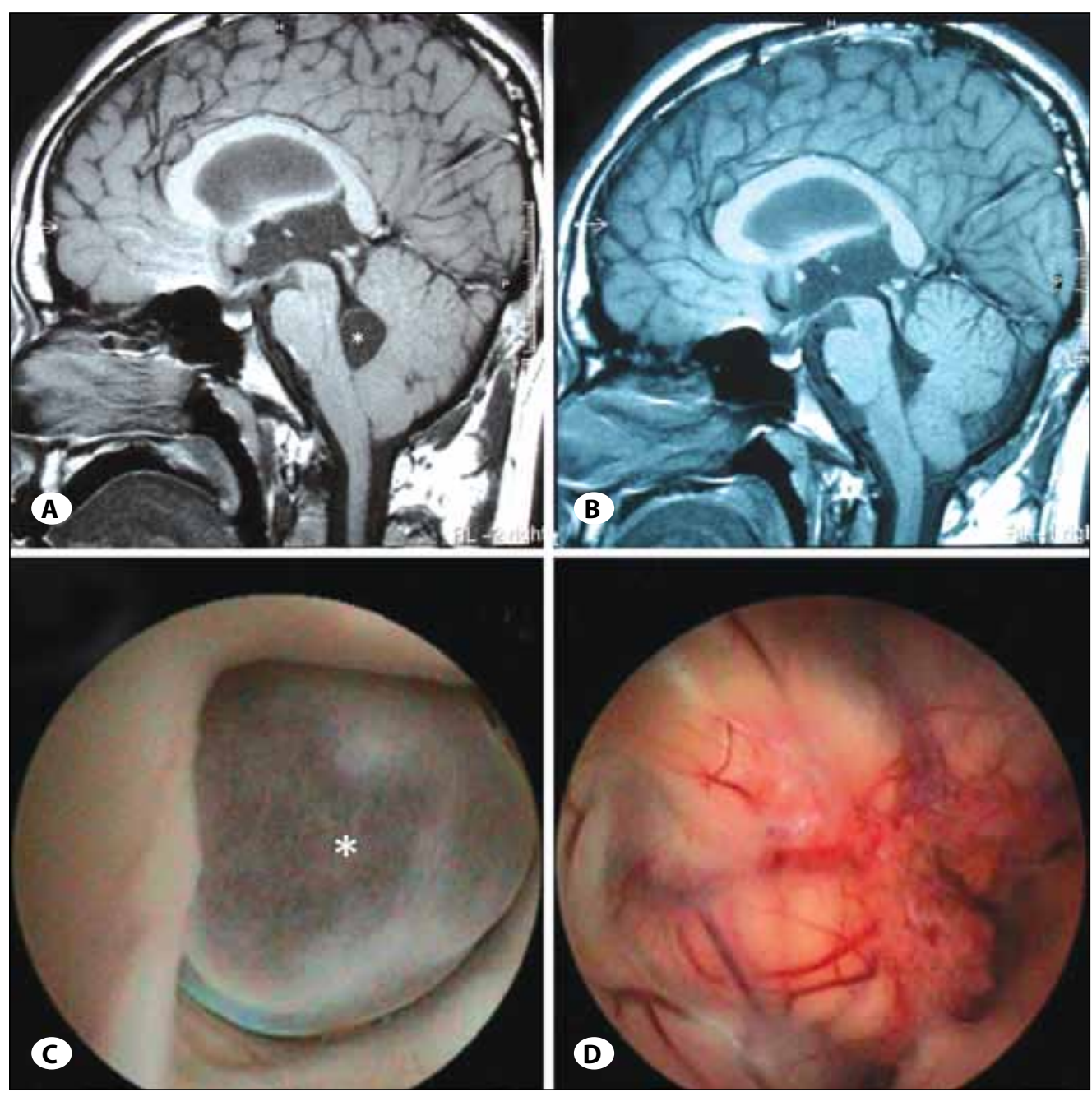

Figure 1: A) Preoperative MRI showed the cystic lesion in the fourth ventricle (asterisk); B) postoperative MRI showed that the lesion was not present; C) the cystic lesion in the fourth ventricle shown from aqueduct under neuroendoscoped (asterisk); D) structure of the fourth ventricle after removal of the lesion. 
lesion in the fourth ventricle combined with multiple cysts with a string-of-beads appearance in the basal cistern (Figure $3 A$ ). On October 26, 2009, transaqueductal removal of fourth ventricular cysticercosis (Figure $3 \mathrm{C}$ ) via a precoronal frontal burr hole with flexible neuroendoscope was performed after endoscopic aqueductoplasty because of the membranous obstruction of the aqueduct (Figure 3B) detected during the course of ventricle exploration, and the shunt, and the stringof-beads multiple cysts in the basal cistern (Figure 3D) were removed simultaneously through the orificium fistulae of the third ventricle floor. There were 5 cysticercosis vesicles altogether. Headache disappeared with no adverse reaction postoperatively. The cystic lesion in the fourth ventricle disappeared and satisfactory CSF flow around the foramen
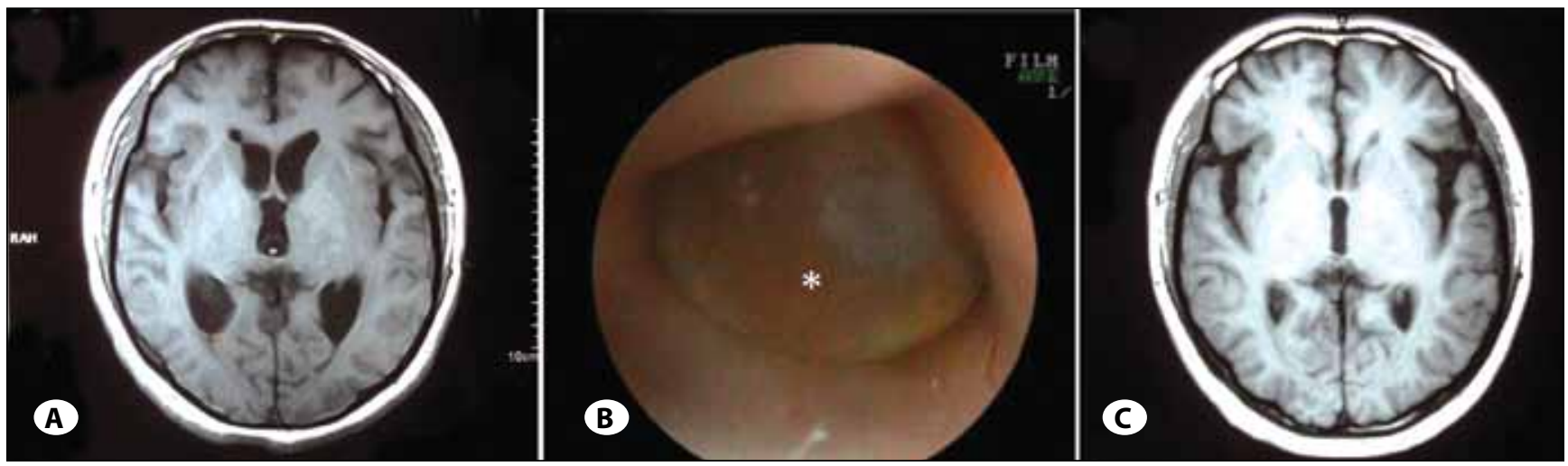

Figure 2: A) Preoperative MRI showed the cystic lesion in third ventricle (asterisk); B) the lesion was seen to have migrated into the fourth ventricle in the course of operation (asterisk); C) postoperative MRI showed that the lesion was not present.
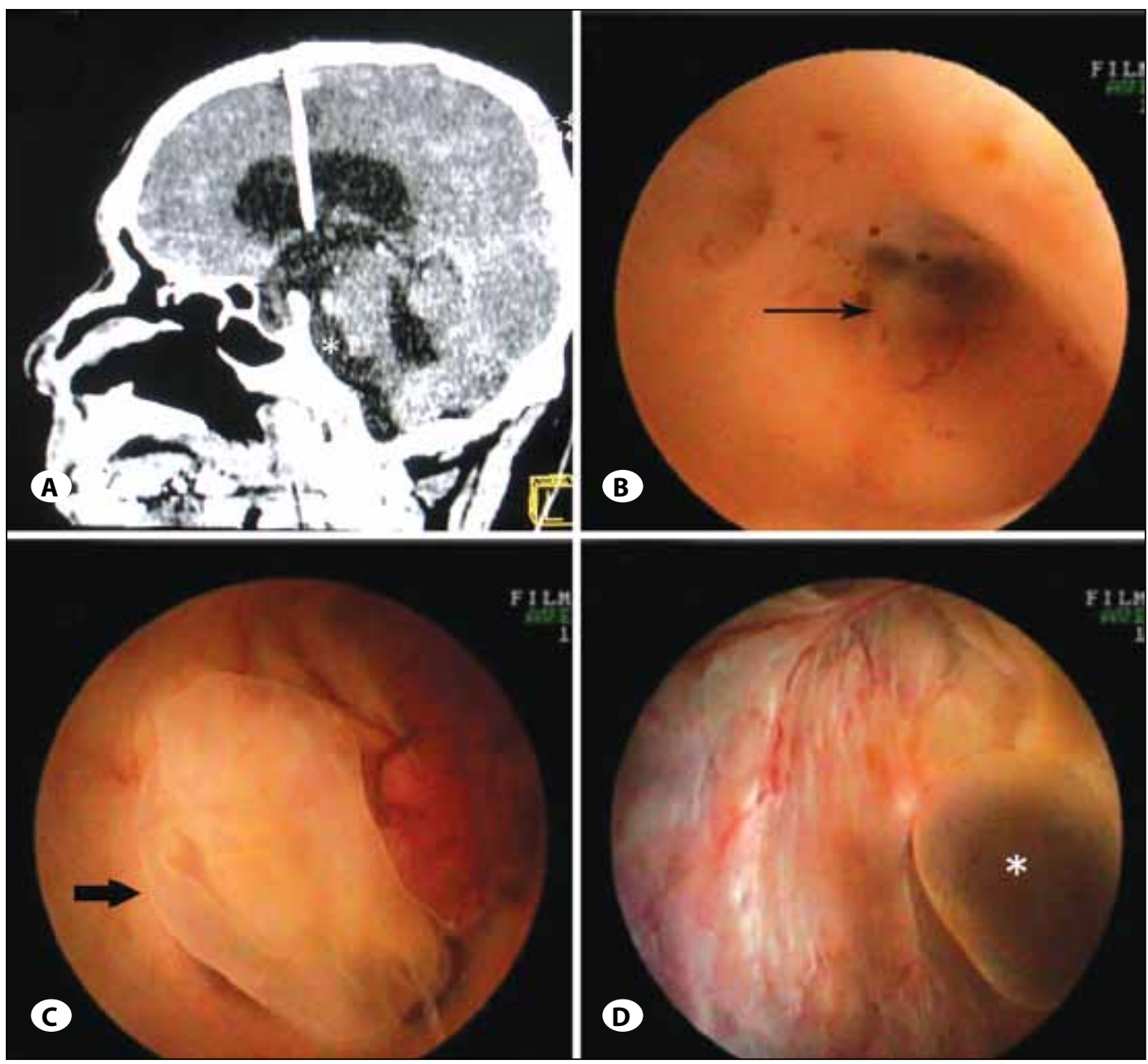

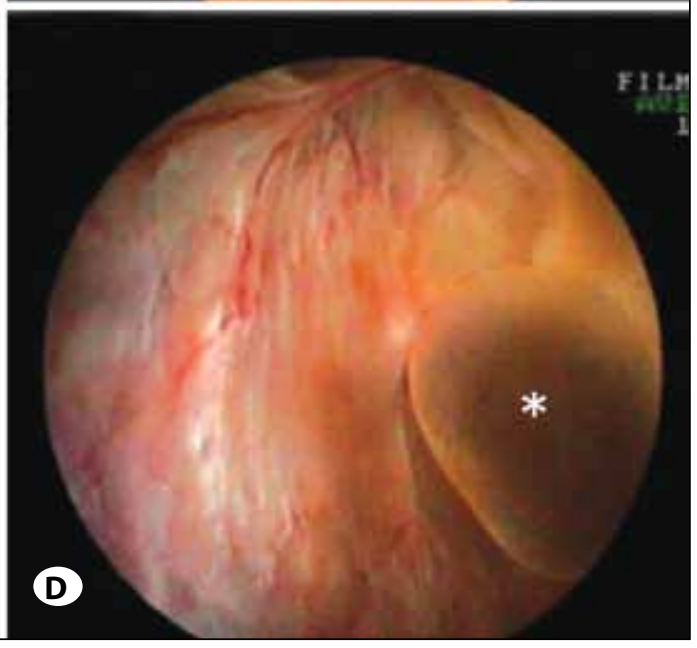

Figure 3:

A) Preoperative sagittal CT showed the cystic lesion in the fourth ventricle combined with string-of-beads multiple cysts in the basal cistern (asterisk); B) the membranous obstruction of the aqueduct detected under the endoscope (arrow); C) the cystic lesion in the fourth ventricle was detected after EAP (arrow); D) the string-of-beads multiple cysts in the basal cistern (asterisk). 
magnum was detected by cine phase-contrast magnetic resonance imaging 6 days after the operation. Diagnosis was confirmed on histology and the patient was discharged from hospital 7 days after the operation.

\section{Endoscopic Procedure}

Endoscopic transaqueductal removal of fourth ventricular cysticercosis was performed through a frontal precoronal burr hole with supine position under general anaesthesia. The FUJINON EB-270P flexible endoscope (diameter 3.8$\mathrm{mm}$, length $30-\mathrm{cm}$ ) was used in our procedure. The surgery was based on the results of the ventricular exploration. Endoscopic forceps and 2F Foley's tube were necessary when the membranous obstruction of the aqueduct appeared. Successful aqueductoplasty is the key to endoscopic transaqueductal removal of fourth ventricular cysticercosis under such circumstances.

It is recommended that cysticercosis uesicaes are removed completely by suction through the endoscope. If suction is difficult, the bipolar electrocoagulator is helpful to crimple the cysticercosis vesicles. Irrigation with normal saline infused with dexamethasone, especially when the cysticercosis vesicles are broken, could resolve the patient's postoperative reaction.

\section{DISCUSSION}

Neurocysticercosis is the most frequently observed parasitosis of the central nervous system worldwide. In China, it is common in the northeastern and northern districts. The fourth ventricle is the most frequent site of intraventricular infestation, a location that carries a higher risk of CSF blockage and resultant intracranial hypertension. Cysticercosis of the fourth ventricle can sometimes cause sudden death (6).

Magnetic resonance imaging is preferred for detecting intraventricular cysticercosis lesions. Fourth ventricular neurocysticercosis usually presents with obstructive hydrocephalus and cystic lesions in the fourth ventricle. Scolex can be detected on MRI in most cases. Serum ELISA for cysticercosis is convenient and helpful for the diagnosis (9).

There is no consensus as to the optimum management of patients who harbor neurocysticercosis. Available treatment options are medical, external cerebrospinal fluid diversion, microsurgical, or endoscopic removal alone or in combination. A treatment algorithm is usually based on patient symptoms, cyst location, and MR imaging $\mathrm{Gd}$ enhancement characteristics (4).

Fourth ventricular neurocysticercosis usually presents with obstructive hydrocephalus. In patients presenting with acute hydrocephalus caused by intraventricular neurocysticercosis, the surgical removal of the cyst has the advantage of eliminating the inflammatory nidus and potentially obviating the need for a complication-prone shunt, compared with the alternative treatment options of anthelmintic medication and/or cerebrospinal fluid shunt placement $(3,5)$. Various surgical approaches to treat intraventricular cysticercosis have been practiced over the years. Suboccipital craniectomy for removal of cysticercal cysts within the fourth ventricle seems to be the standard choice in most hospitals.

Endoscopic excision is becoming increasingly popular following with the development of endoscopic equipment and skills $(7,12)$. Transforaminal endoscopic removal of third ventricular cysticercosis lesions is feasible, but it is difficult if the lesion migrates into the fourth ventricle. Neal $\mathrm{JH}$ has reported attempted removal of a third ventricular cysticercosis cyst by an endoscopic approach aborted before surgery when a preoperative scan demonstrated migration of the cyst into the fourth ventricle (11). He therefore proposed immediate preoperative imaging to rule out migration of the lesion.

The literature regarding the use of endoscopic excision of fourth ventricular cysticercosis is scarce $(1,2,4,8,10,13,14)$. This is the first report of endoscopic transaqueductal removal of fourth ventricular cysticercosis with electrical flexible neuroendoscopy in China.

Sometimes, the cysticercosis vesicles are multiple but isolated, and can migrate in the ventricular system. The electrical flexible neuroendoscopy has distinct advantages to remove the cysticercosis uesicaes due to its soft, fine and smooth. The diameter of the neuroendoscope we used was only $3.8 \mathrm{~mm}$. Besides overall exploration to the supratentorial ventricular system, we could easily pass through the winding narrow aqueduct to reach and operate in the fourth ventricle with it under the circumstances of no injury. There were minimal periand postoperative complications. Shunt placement and its related complications can be avoided. The whole ventricular system can be explored easily with the electrical flexible neuroendoscope. Endoscopic fourth ventricular cysticercal cyst excision, especially operating with an electrical flexible neuroendoscope, should be recommended as the optimal choice of the disease due to its minimal invasiveness, fewer complications, shorter length of stay and cheaper treatment costs.

\section{CONCLUSION}

Every corner of the ventricular system can be explored easily with flexible neuroendoscope. The cysticercosis vesicles in the ventricular system are usually multiple but isolated. Removal of ventricular cysticercosis with flexible neuroendoscope is very convenient and has distinctive advantages.

\section{REFERENCES}

1. Anandh B, Mohanty A, Sampath S, Praharaj SS, Kolluri S: Endoscopic approach to intraventricular cysticercal lesions. Minim Invasive Neurosurgery 44(4): 194-196, 2011

2. Bergsneider M: Endoscopic removal of cysticercal cysts within the fourth ventricle. Journal of Neurosurgery 91(2): 340-345, 1999 
3. Cappabianca P, Cinalli G, Gangemi M, Brunori A, Cavallo LM, de Divitiis E, Decq P, Delitala A, Di Rocco F, Frazee J, Godano U, Grotenhuis A, Longatti P, Mascari C, Nishihara T, Oi S, Rekate H, Schroeder HW, Souweidane MM, Spennato P, Tamburrini G, Teo C, Warf B, Zymberg ST: Application of neuroendoscopy to intraventricular lesions. Neurosurgery 62 Suppl 2: 575-597, 2008

4. Citow JS, Johnson JP, McBride DQ, Ammirati M: Imaging features and surgery-related outcomes in intraventricular neurocysticercosis. Neurosurgical Focus 12(6): e6, 2002

5. Goel RK, Ahmad FU, Vellimana AK, Suri A, Chandra PS, Kumar R, Sharma BS, Mahapatra AK: Endoscopic management of intraventricular neurocysticercosis. Journal of Clinical Neuroscience 15(10): 1096-1101, 2008

6. Hortobagyi T, Alhakim A, Biedrzycki O, Djurovic V, Rawal J, AlSarraj S: Cysticercosis of the fourth ventricle causing sudden death: a case report and review of the literature. Pathology Oncology Research 15(1): 143-146, 2009

7. Husain M, Jha DK, Rastogi M, Husain N, Gupta RK: Neuro-endoscopic management of intraventricular neurocysticercosis (NCC). Acta Neurochirurgica 149(4): 341-346, 2007

8. Husain M, Rastogi M, Jha DK, Husain N, Gupta RK: Endoscopic transaqueductal removal of fourth ventricular neurocysticercosis with an angiographic catheter. Neurosurgery 60(4 Suppl 2): 249-254, 2007
9. Jiang ZD, Lou FY, Zhang SJ: Diagnosis and treatment of neurocysticercosis of the fourth ventricle. Journal of Clinical Neurosurgery 5(2): 70-72, 2008

10. Lapergue B, Hosseini $H$, Liance M, Rosso C, Decq P: Hydrocephalus and racemose cysticercosis: Surgical alternative by endoscopic third ventriculostomy. Neurochirurgie 51(5): 481488, 2005

11. Neal JH: An endoscopic approach to cysticercosis cysts of the posterior third ventricle. Neurosurgery 36(5): 1040-1043, 1995

12. Psarros TG, Coimbra C: Endoscopic third ventriculostomy for patients with hydrocephalus and fourth ventricular cysticercosis: A review of five cases. Minimally Invasive Neurosurgery 47(6): 346-349, 2004

13. Suri A, Goel RK, Ahmad FU, Vellimana AK, Sharma BS, Mahapatra AK: Transventricular, transaqueductal scopein-scope endoscopic excision of fourth ventricular neurocysticercosis: A series of 13 cases and a review. Journal of Neurosurgery Pediatrics 1(1): 35-39, 2008

14. Zymberg ST, Paiva Neto MA, Gorgulho AA, Cavalheiro S: Endoscopic approach to fourth ventricle cysticercosis. Arquivos de Neuro-psiquiatr 61(2A): 204-207, 2003 